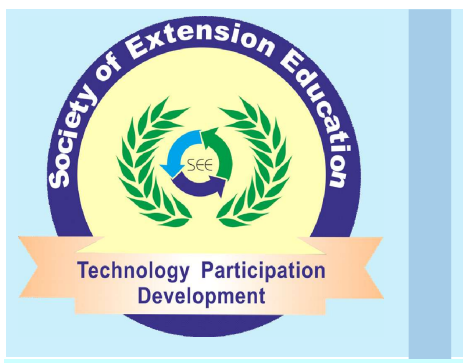

Research Article

\section{Indian Research Journal of Extension Education}

ISSN: 0972-2181 (Print), 0976-1071 (Online)

NAAS Rating : 5.22

Journal homepage: seea.org.in

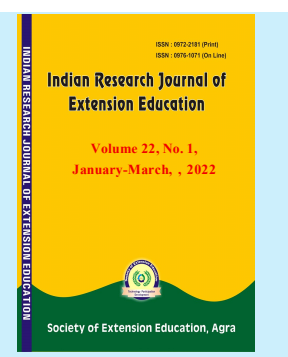

https://doi.org/10.54986/irjee/2022/jan_mar/81-85

\title{
Role of Psychological Attributes of DAESI Dealers in Knowledge and Skill Development
}

\author{
Twinkle Handa ${ }^{1}$, M.A. Khan ${ }^{2}$ and H.K. Awasthi ${ }^{3}$ \\ 1. Ph. D. Scholar, 2 \&3. Prof., Dept. of Agricultural Extension, College of Agriculture, I.G.K.V., Raipur, C.G., India \\ Corresponding author e-mail : twinstartwinkle0503@gmail.com
}

Paper Received on July 31, 2021, Accepted on November 11, 2021 and Published Online on January 01, 2022

\begin{abstract}
Psychological attributes are the internal human characteristics which reflect a great impact over the trainees of any programmme. These attributes are distinct for each and everyone. National Institute of Agricultural Extension Management (MANAGE) had launched a individual financed One-year Diploma in Agricultural Extension Services for Input Dealers (DAESI) Programme during the year 2003 for the input dealers in order to make input dealer competent enough in terms of knowledge and skill. In Chhattisgarh, under the flagship of Indira Gandhi Krishi Vishwavidhayalaya Raipur, Directorate of Extension Services had initiated a yearly Diploma course which was started in the year 2017-18. This study is focused to access the role of Psychological Attributes of DAESI dealers in knowledge and skill development. a random sample of 100 participants were selected out of 154 participants. The data was collected through a well prepared Questionnaire \& need based online data methods and ex-post facto research design was used. The study reveals that majority of respondents were moderately benefited from DAESI programme 2019-20 in terms of increase in knowledge and gain in skills. Correlation and path analysis between various psychological attributes and increase in knowledge \& gain in skill reveals that three attributes namely, innovativeness, risk bearing ability and self-confidence is considered the most important and determining attribute for increase in knowledge and skill level of DAESI dealers.
\end{abstract}

Key words : Psychological attributes; DAESI dealers; DAESI programme; Increase in knowledge; Gain in skill.

$\mathbf{P}_{\text {sychological attributes of an individual are distinct }}$ due to variation amongst people's characteristics and behavioral patterns. Input dealers are the major source for paradigm shift in Indian Agriculture. They act as major source for information dissemination in rural areas. For building their technical competency, assessment of Psychological Attributes is necessary as assessment is the first step of understanding the attributes. A single year Diploma course with the title of 'Diploma in Agricultural Extension Services for Input dealers (DAESI) was launched by MANAGE (National
Institute of Agriculture Extension Management) to incorporate the necessary understanding and the location specific agricultural education. In Chhattisgarh, under the flagship of Indira Gandhi Krishi Vishwa Vidhayalaya Raipur, Directorate of Extension Services had initiated a yearly Diploma course which was started in the year 2017-18. The mission of DAESI programme is complete transformation of agri-input dealers into individuals who act as "Para-Extension Professionals" thereby helping in the agricultural extension system so as to make them competent enough to help the farmers efficiently. 
The objective of the present study is to access the psychological attributes of DAESI dealers and their role in knowledge and skill development.

\section{METHODOLOGY}

The current study was carried out in four purposely selected KVKs of Raipur, Dhamtari, Rajnandgaon and Raigarh districts implementing DAESI Programme in 2019-20. As per the list of participants provided by the respective four $\mathrm{KVK}$, all the 154 trainees/ agri-input dealers trained during 2019-20 were approached and a random sample of 100 participants were selected out of 154 participants. The data was collected through a well prepared Questionnaire and need based online data methods like e-mail, telephone calls, Google forms, etc and ex-post facto research design was used. Data were analyzed using frequency distribution, per centage, mean, standard deviation, SPSS and OPSTAT software. Moreover, increase in knowledge and gain in skill was measured using four-point continuum ranging from not benefited to highly benefited and an overall index was calculated.

$$
\text { Overall index }=\frac{\text { Obtainable score }}{\text { Max. possible score }} \times 100
$$

\section{RESULT AND DISCUSSION}

Many input dealers had attended DAESI programme and got benefitted. The psychological attributes of DAESI dealers is presented in Table 1. The outcome is portrayed as follows

Innovativeness : Regarding innovativeness, more than three-fourth $(77.00 \%)$ of the agri-input dealers who had attended DAESI programme had medium level of innovativeness, followed by 16.00 per cent belonging to low level of innovativeness and 7.00 per cent belonging to high level of innovativeness.

Management orientation: The results regarding management orientation, reveals that 57.00 per cent of the agri- input dealers of agricultural product had management orientation in the medium range followed by 22.00 per cent of the individuals who had management orientation in the higher range followed by 21.00 per cent of the individuals who had management orientation in the lower range. The result was consistent with the findings reported by Srinivas (2013), Mamatha, D.N. (2018) and Jally (2019).

Risk bearing ability: With regard to the risk bearing
Table 1. Distribution of DAESI dealers according to their Psychological attributes

\begin{tabular}{lll}
\hline Attributes & No. & $\%$ \\
\hline Innovativeness & & \\
Low $(<12$ score $)$ & 16 & 16.00 \\
Medium $(12-17$ score $)$ & 77 & 77.00 \\
High $(>17$ score $)$ & 7 & 7.00 \\
$\bar{X}=14.29 \quad \sigma=2.75$ & & \\
Management orientation & & \\
Low $(<20$ score $)$ & 21 & 21.00 \\
Medium $(20-27$ score $)$ & 57 & 57.00 \\
High $(>27$ score $)$ & 22 & 22.00 \\
$\bar{X}=23.59 \quad \sigma=3.372$ & & \\
Risk bearing ability & & \\
Low $(<19$ score $)$ & 15 & 15.00 \\
Medium $(19-26$ score $)$ & 72 & 72.00 \\
High $(>26$ score $)$ & 13 & 13.00 \\
$\bar{X}=22.27 \quad \sigma=3.28$ & & \\
Self confidence & & \\
Low $(<24$ score $)$ & 17 & 17.00 \\
Medium $(24-32$ score $)$ & 65 & 68.00 \\
High $(>32$ score $)$ & & \\
$\bar{X}=38.24 \quad \sigma=4.01$ & 15 & 15.00 \\
Economic motivation & & \\
Low $(<21$ score $)$ & & \\
Medium $(21-27$ score $)$ & & \\
High $(>27$ score $)$ & & \\
$\bar{X}=23.9 \quad \sigma .00$ \\
\hline
\end{tabular}

ability, majority $(72.00 \%)$ of the agri-input dealers were having medium level of risk bearing ability followed by low level of risk bearing ability (15.00\%) and high level of risk bearing ability $(13.00 \%)$. This finding was consistent with the findings reported by Reddy et al. (2020).

Self-confidence : Findings in accordance with selfconfidence indicates that majority $(68.00 \%)$ of the agriinput dealers were categorized under medium level of self-confidence followed by low level of self-confidence $(17.00 \%)$ and high level of self-confidence $(15.00 \%)$.

Economic motivation: The results regarding economic motivation, the higher proportion $(65.00 \%)$ of agri-input dealers who had attended DAESI programme 2019-20 having medium economic motivation followed by 21.00 per cent being in the category of high economic motivation and 14.00 per cent in the category of low economic motivation. This finding was consistent with the findings reported by Todase (2010), Fuke (2011), Waghmode (2012) and Jally (2019). 
Impact of DAESI programme on knowledge and skill level: Data pertaining to Table 2 reveals that majority of the DAESI dealers had medium level of increase in knowledge $(68.00 \%)$ followed by high level of increase in knowledge $(18.00 \%)$ and low level of increase in knowledge (17.00\%) after availing DAESI programme. The overall index in reference to increase in knowledge was 67.00 per cent. The probable reason for medium increase in knowledge level may be pandemic season as majority of the classes of diploma course had organized online which had created a communication barrier between DAESI dealers and resource person.

Data pertaining to Table 2 also reveals that majority of the DAESI dealers had medium level of skill acquired $(81.00 \%)$ followed by low level of skill acquired $(13.00 \%)$ and high level of skill acquired (6.00\%) after availing DAESI programme. The overall index in reference to gain in skills was 64.33 per cent. The probable reason for medium increase in skill level is low frequency of field visits and practical sessions. All skills can't be learned online. Pandemic sessions had not only affected the economic condition of the world but also affected the various ongoing programmes by the government in agricultural field. Diploma course in the same manner is worstly affected.

Table 2. Distribution of respondents according to the level of knowledge and skill acquired by DAESI programme

\begin{tabular}{lllll}
\hline Particulars & \multicolumn{2}{l}{$\%$ of respondents } & \multicolumn{2}{l}{ Overall } \\
& High & Medium & Low & index $(\%)$ \\
\hline Increase in knowledge & 18.00 & 65.00 & 17.00 & 67.00 \\
Gain in skills & 6.00 & 81.00 & 13.00 & 64.33 \\
\hline
\end{tabular}

Role of psychological attributes in increase in knowledge of DAESI dealers : Relationship between the scores of selected psychological attributes and increase in knowledge level were tested by null hypothesis and empirical hypotheses. Correlation coefficient (r) was computed and the values are presented in the Table 3.

Table 3 reveals that management orientation, innovativeness, risk bearing ability, and self-confidence
Table 3. Correlation co-efficient between increase in knowledge and psychological attributes of DAESI dealers after attending DAESI programme $(N=100)$

\begin{tabular}{ll}
\hline Psychological attributes & $(\mathrm{r})$ \\
\hline Management orientation & $0.391^{* *}$ \\
Innovativeness & $0.835^{* *}$ \\
Risk bearing ability & $0.780^{* *}$ \\
Economic motivation & $0.284^{*}$ \\
Self confidence & $0.750^{* *}$ \\
\hline
\end{tabular}

**Significance at 0.01 probability level,

*Significant 0.05 probability level

had significantly and highly correlated with increase in knowledge of DAESI dealers after availing DAESI programme at 1 per cent level of significance. While, Economic motivation is significantly correlated with increase in knowledge of DAESI dealers after availing DAESI programme at 5 per cent level of significance. All the psychological attributes are positively correlated which suggest that the increase in knowledge level of DAESI dealers increases with the increase in various psychological potential. Hence, it can infer that Psychological attributes had a great impact over increase in knowledge of DAESI dealers. The results were in conformity with Kumar et al. (2014), Srinivas (2013), Mamatha, D. N. (2018), and Jally (2019).

Path analysis of psychological attributes with increase in knowledge of DAESI dealers : The main objective of path analysis in the present study is to get a clear picture of the direct and indirect effects of the psychological attributes on dependent variable i.e. increase in knowledge. The four psychological attributes whose regression values were significant in the final multiple regression analysis was included in the path analysis which is depicted in the Table 4 presenting the matrix of path analysis. The psychological attribute i.e. innovativeness $(0.439)$ had the highest positive and substantial direct effect on increase in knowledge. There were positive and substantial direct effects of selfconfidence $(0.291)$ and risk bearing ability $(0.298)$ on increase in knowledge. It is also evident from Table 4 that substantial indirect effects of as many as four

Table 4. Matrix of path analysis

\begin{tabular}{lcccc}
\hline & Management orientation & Innovativeness & Risk bearing ability & Self-confidence \\
\hline Management orientation & 0.0761 & 0.1369 & 0.0980 & 0.093 \\
Innovativeness & 0.02374 & 0.43951 & 0.2059 & 0.18114 \\
Risk bearing ability & 0.0250 & 0.30337 & 0.29843 & 0.17516 \\
Self confidence & 0.0244 & 0.2726 & 0.17905 & 0.29195 \\
\hline
\end{tabular}


variables were challenged through each of the three independent variables i.e. Innovativeness, risk bearing ability and self-confidence. These three variables had more direct substantial effect on the dependent variable. They also formed a complete chain in mutually interacting variables. These three variables, therefore, be considered most important for the increase in knowledge of DAESI dealers who had attended DAESI programme 2019-20.

Role of psychological attributes in Gain in skill by DAESI dealers : Relationship between the scores of selected psychological attributes and gain in skill were tested by null hypothesis and empirical hypotheses. Correlation coefficient ( $r$ ) was computed and the values are presented in the Table 5.

Table 5. Correlation co-efficient between gain in skill and psychological attributes of DAESI dealers after attending DAESI programme $(\mathrm{N}=100)$

\begin{tabular}{ll}
\hline Psychological attributes & $(\mathrm{r})$ \\
\hline Management orientation & $0.414^{* *}$ \\
Innovativeness & $0.772^{* *}$ \\
Risk bearing ability & $0.769^{* *}$ \\
Economic motivation & $0.312^{* *}$ \\
Self confidence & $0.726^{* *}$ \\
\hline
\end{tabular}

** Significance at 0.01 probability level

Table 5 reveals that management orientation, innovativeness, risk bearing ability, economic motivation and self-confidence had significantly and highly correlated with increase in knowledge of DAESI dealers after availing DAESI programme at 1 per cent level of significance. All the psychological attributes are positively correlated which suggest that the gain in skills by the DAESI dealers increases with the increase in various psychological potential. Hence, it can infer that Psychological attributes had a great impact over gaining various training skills by DAESI dealers. The results were in conformity with Mamatha, D. N. (2018).

Path analysis of psychological attributes with Gain in skill by DAESI dealers
The main objective of path analysis in the present study is to get a clear picture of the direct and indirect effects of the psychological attributes on dependent variable i.e. gain in skill. The four psychological attributes whose regression values were significant in the final multiple regression analysis was included in the path analysis which is depicted in the Table 6 presenting the matrix of path analysis.

The psychological attribute i.e. risk bearing ability (0.340) had the highest positive and substantial direct effect on increase in knowledge. There were positive and substantial direct effects of innovativeness (0.328), self-confidence (0.289) and management orientation $(0.113)$ on gain in skills by DAESI dealers. It is also evident from Table 6 that substantial indirect effects of as many as four variables were challenged through each of the three independent variables i.e. innovativeness, risk bearing ability and self-confidence. These three variables had more direct substantial effect on the dependent variable. They also formed a complete chain in mutually interacting variables. These three variables, therefore, be considered most important for the gain in skill by DAESI dealers who had attended DAESI programme 2019-20.

\section{CONCLUSION}

On the basis of above findings, it can be concluded that 68.00 per cent of the DAESI dealers had increase in their knowledge level in medium range succeeded by 18.00 per cent who had experienced a high increase in their knowledge level succeeded by 17.00 per cent who had a low increase in the knowledge level after availing DAESI programme. Similarly, majority $(81.00 \%)$ of the DAESI dealers had medium range of gain in skills followed by low range of gain in skills $(13.00 \%)$ and high range of gain in skills $(6.00 \%)$ after availing DAESI programme. This suggest that more emphasis should be given to field visits, demonstrations, etc so that skill development should be primarily focussed by DAESI Programme. Correlation and path analysis between

Table 6. Matrix of path analysis

\begin{tabular}{lcccc}
\hline & Management orientation & Innovativeness & Risk bearing ability & Self confidence \\
\hline Management orientation & 0.11340 & 0.1022 & 0.1120 & 0.09268 \\
Innovativeness & 0.0353 & 0.32825 & 0.2353 & 0.1793 \\
Risk bearing ability & 0.03727 & 0.22658 & 0.3409 & 0.17344 \\
Self confidence & 0.03636 & 0.20366 & 0.20454 & 0.28908 \\
\hline
\end{tabular}


various psychological attributes and increase in knowledge reveals that there were positive and substantial direct effects of innovativeness, selfconfidence and risk bearing ability whereas these three attributes also formed a complete chain in mutually interacting variables due to their substantial indirect effects. In the same manner, Correlation and path analysis between various psychological attributes and gain in skills reveals that there were positive and substantial direct effects of innovativeness, selfconfidence, management orientation and risk bearing ability whereas three attributes (innovativeness, self-confidence and risk bearing ability) also formed a complete chain in mutually interacting variables due to their substantial indirect effects. The decree of the investigation concluded that innovativeness, selfconfidence and risk bearing ability were the major psychological attributes affecting DAESI dealers in knowledge and skill development through DAESI programme.

\section{CONFLICTS OF INTEREST}

The authors declare that they have no conflicts of interest

\section{REFERENCES}

Guidelines for operationalization of Diploma in Agricultural Extension Services for Input Dealers (DAESI) Programme. Published by Dept. of Agriculture and Cooperation, Ministry of Agriculture and Farmer's Welfare, Govt. of India. https:// www.manage.gov.in/daesi/daesi.asp

Fuke, A.B. (2011). Role of agro-service centres in agricultural development. M.Sc.(Ag.) Thesis (Unpub.). Dr. Panjabrao Deshmukh Krishi Vidyapeeth, Akola, Maharashtra.

Jally, Chinmayee. (2018). Study on impact of diploma in agricultural extension services for input dealers (DAESI) in Odisha. M.Sc. (Ag.). Indira Gandhi Krishi Viswhavidhayalaya, Raipur(Chattisgarh).

Kumar, S.; Singh, S.R.K. and Sharma, R.C. (2014). Farmers knowledge level on organic cultivation in Madhya Pradesh. Indian Res. J. Extn. Edu., 14 (3):131-133.

Mamatha D. N. (2018). Impact of diploma in agricultural extension services of input dealers (DAESI) training on agricultural input dealers. M.Sc.(Ag.). Univ. Agric. Sci., Bengaluru.

Reddy, U. K. K.; Satyagopal, P.V.; Sailajaand, V.; Prasad, S.V. (2020). Profile characteristics of agri- input dealers. Department of Agricultural Extension, S.V. Agricultural College, ANGRAU, Tirupati 517502, Chittoor (Dist), Andhra Pradesh.

Srinivas, E. (2013). A critical analysis of diploma in agricultural extension services for input dealers (DAESI) programme in Andhra pradesh. Ph.D. (Agri.) Thesis, Acharya N. G. Ranga Agric. Univ., Hyderabad.

Todase, J.V. (2010). Training needs of fertilizer dealers from Konkan and Vidarbha Region of Maharashtra State. M.Sc. (Ag.) Thesis (Unpub.), Dr. Balasaheb Sawant Konkan Krishi Vidyapeeth, Dapoli, Maharashtra.

Waghmode, Y.J. (2012). Training needs of agricultural input dealers in transfer of agriculture technology in Ratnagiri District M.Sc.(Ag.). Thesis (Unpub.), Dr. Balasaheb Sawant Konkan Krishi Vidyapeeth, Dapoli, Maharashtra. 